\title{
MAPPING OF FLOOD SUSCEPTIBILITY IN CAMPINA GRANDE COUNTY - PB: A SPATIAL MULTICRITERIA APPROACH
}

\author{
Mapeamento da susceptibilidade a alagamentos em Campina Grande - PB: \\ uma abordagem multicriterial
}

Priscila Barros Ramalho Alves ${ }^{1}$ - ORCID: 0000-0003-3489-8552

Hiran de Melo Filho;

Bárbara Barbosa Tsuyuguchi ${ }^{1}$ - ORCID: 0000-0002-7649-8779

Iana Alexandra Alves Rufino² - ORCID: 0000-0003-0450-4647

Patrícia Hermínio Cunha Feitosa ${ }^{1}$
${ }^{1}$ Universidade Federal de Campina Grande, Pós-graduação em Engenharia Civil e Ambiental, Campina Grande/PB, Brasil.
E-mail: priscilabramalho@gmail.com;_barbara.tsuyu@gmail.com; iana.alexandra@ufcg.edu.br; phcfeitosa@outlook.com
${ }^{2}$ Fronteira Engenharia Inc., Campina Grande/PB, Brasil.
E-mail: hiranfilho@gmail.com

Received in June $16^{\text {th }}, 2017$.

Accepted in November $4^{\text {th }}, 2017$.

\section{Abstract:}

The social and economic impacts caused by floods in urban areas are diverse and increase as the land becomes gradually impervious. Due to the increasing urbanization of cities, it is necessary to implement a better planning process and optimize the urban spaces management and occupation. Thus, the government needs to gather reliable and useful data for the decision-making process. Therefore, the GIS plays an important role among urban planning instruments. Given the current situation in Campina Grande County, Paraiba State, Brazil - an area continually facing disturbances caused by occasional and concentrated rainfalls - the current study aims to map the areas seen as the most susceptible to floods, by using a MCDA GIS-based model (Multi-Criteria Decision Analysis). There are five quantitative criteria considered in the analysis: slope, altitude, roads with drainage infrastructure, distance from water bodies and land use. It is a pixel by pixel analysis based on predetermined assumptions. Fuzzy functions were developed and overlay operations were performed. The results were consistent with historical records and with previous studies about the county, thus adding reliability to the model, which can be considered a potential management instrument for the case study area, as well as for cities facing similar issues.

Keywords: Floods; Urbanization; GIS; MCDA; Fuzzy.

How to cite this article: Alves, P.B.R., et al. Mapping of flood susceptibility in Campina Grande county - PB: a spatial multicriteria approach. Bulletin of Geodetic Sciences, Vol. 24, issue 1, 28-43, Jan-Mar, 2018. 


\section{Resumo:}

Os impactos sociais e econômicos que alagamentos podem causar em áreas urbanas são diversos e aumentam à medida que o solo é impermeabilizado. O aumento de urbanização das cidades, torna necessário implementar um melhor processo de planejamento e otimizar a gestão do espaço urbano e sua ocupação. Para isso, as gestões precisam de dados confiáveis e úteis para a tomada de decisão. Assim, os Sistemas de Informação Geográfica (SIG) têm papel importante entre os mecanismos de planejamento urbano. Diante da atual situação do município de Campina Grande, Paraíba - Brasil, palco de transtornos de chuvas esporádicas e concentradas, esse estudo objetivou mapear as áreas mais susceptíveis a ocorrência de alagamentos através de um modelo baseado em SIG e MCDA (Multi-Criteria Decision Analysis). Consideraram-se cinco critérios quantitativos: declividade, altitude, vias com drenagem, distância a corpos hídricos e uso do solo. A análise ocorreu pixel a pixel baseada em premissas pré-determinadas, foram criadas funções de pertinência Fuzzy e efetuadas operações de sobreposição (overlay). Os resultados foram compatíveis com registros históricos, levantamentos oficiais e estudos prévios elaborados para a cidade, agregando confiabilidade ao modelo. Este pode ser considerado como um instrumento de gestão para o caso estudado e para cidades com problemas similares.

Palavras-chave: Alagamentos; Urbanização; SIG; MCDA; Fuzzy.

\section{Introduction}

There was a quite significant movement in the second half of the 20th century in Brazil, which is popularly known as "rural exodus." It seems to have become an irreversible and preponderant process worldwide: approximately $70 \%$ of the world's population will be living in urban areas by 2050 (World Bank 2014). In addition, a survey conducted by the International Monetary Fund (IMF) and by the International Labor Organization (ILO) has shown that the phenomenon should bring 30 million people per year to urban centers, throughout the aforementioned decade.

That survey can be a warning about the need to adapt, expand and make the urban infrastructure (mainly the basic sanitation) more efficient to enable the cities to provide quality of life to their populations. According to Tucci (2007), the increased density impacts the soil imperviousness as it becomes necessary building streets, roofs, among others. Therefore, there is reducing soil infiltration capacity, which increases the possibility of having floods resulting from rainy events.

According to Shaw et al. (2011), the occurrence of floods has no news; however, the potential damage resulting from phenomena such as floods has increased over the years. Nowadays, the social and economic impacts caused by floods are stronger than they were a few decades ago. It happens because when the water invades the new (recent) industries, which have expensive electronic equipment, it generates losses of much higher proportions than it did in the past when heavy industry prevailed - similarly, comparing the current residences to those built in the last centuries. In addition, the intense vehicular traffic in large cities turns flooding into an urban mobility issue.

In short, the expansion of urban centers increases their susceptibility to flooding. In addition, the advancement of technology and the increasing concentration of people in urban areas increase the damages resulting from flood events (Ferreira and Valverde 2013; Miller et al. 2014; Alfy 2016). The urbanized areas are proportional to the flooded areas during flood events (Ferreira and 
Valverde 2013). Therefore, it is necessary developing different flood risk management strategies from the traditional urban drainage ones, since they are very focused on purely structural interventions, such as piped solutions and water canals, which sometimes cause problems to the population.

NVE (2012) has emphasized the importance of breaking up with the "traditional" management paradigm in order to promote the sustainable surface water management through an integrated and holistic approach. In other words, the emphasis should be placed on what the authors call prevention (avoiding and minimizing future flood risk increases), protection (reducing the likelihood of flooding, as well as its impacts, through structural and, mainly, non-structural interventions) and preparedness (carrying out flood forecasts and issuing prior notices to alert the citizens and competent authorities).

The third element of the triad proposed by the authors above is what can be termed as flood "warning system" (Amorim et al. 2014; Oliveira 2011). The entire Australian territory, for instance, is covered by this type of system, which is mostly managed by the National Bureau of Meteorology (Wilson et al. 2014). According to the authors, flood forecasts and timely alerts help public agencies to minimize material and human losses. Overall, the studies and analyses supporting the emission of warnings by these organs based on hydrological data and modeling.

In addition to the hydrological modeling, other aspects may be explored in order to map areas most susceptible to flooding. Meyer, Scheuer and Dagmar (2009) have pointed out that, despite the vast amount of scientific studies using multicriteria analyses in their approaches, few studies apply this tool to the flood management context, although its use may produce valuable results. The multi-criteria analysis is based on mapping variables per information plane and on defining the membership degree of each information plan (valuation), as well as of each of its caption components, to find the final result (Moura, 2007).

The aim of the current study was to map areas showing high susceptibility to flooding in Campina Grande County (PB), based on spatial multicriteria analyses in a GIS (Geographic Information System) software. The GIS software used is the ArcGIS ${ }^{\circledR}$ software, developed by ESRI. The results of the present study should support decision-making processes among municipal policy-makers responsible for managing urban waters since these results, enable taking a more strategic action and having a more integrated view of the urban land use and occupation aspects.

\section{Spatial Multicriteria Analysis: Conceptual Analysis}

A multi-criteria analysis requires a series of procedures (and associated factors) that, as a rule, aim to support the decision-making process in complex situations. On the other hand, according to Malczewski (2006), Geographic Information Systems may be used as "an environment that transforms and combines spatial data and expert preferences to support the decision-making process." Thus, it is possible inferring that a GIS simultaneously works as an Information System and as a Decision Support System (Goodchild and Kemp 1990) in some cases and that it allows making multicriteria analyses.

The decision-making process science has been hardly explored; thus, there is an extensive literature available about it. According to Kleindorfer et al. (1993), decision-making may be defined as "an intentional and reflective choice in response to a perceived need". Bazerman (2006) has also mentioned the influence of ideological and affective aspects of people's decision-making 
process. Other authors such as Kahneman and Tversky (2000), Connolly et al. (2000), Smith et al. (2004), Koehler and Harvey (2005) and Hotaling, Fakhari and Busemeyer (2015) have highlighted different approaches and applications, as well as the most used mathematical or statistical methods.

However, the multicriteria analysis applied to the decision-making process has led to changes in the roles played by the actors involved in this science. According to Roy and Vincke (1981), a multicriteria approach adds value to the decision maker, since the issues will no longer be solved by replacing the decision maker with the result provided by an optimization or simulation model. According to the multicriteria approach, the decision making may be better supported, from a plurilateral perspective, if one takes into consideration the selected criteria. The state of the art literature surveyed by Meyer, Scheuer and Dagmar 2009 has shown a wide range of published books and scientific articles approaching the multicriteria analysis to support the decision-making or MCDA (multi-criteria decision analysis). Further studies have been published since then: Wang et al. (2009), Ho, Xu and Dey (2010), Dheena and Mohanraj (2011), Lakicevic et al. (2014), Chang, Yeh and Chang (2013), Chen and Hong (2014) and Tan, Yi and Chen (2015). The MCDA studies published over the last few years comprise several knowledge fields, from the environmental to the social and human sciences, given the endless possibilities of combinations and analyses that such a system allows.

According to Malczewski (2006), the advances in geospatial technology, mainly the incorporation of multicriteria operators into GIS packages, allowed inferring that the interaction between GIS and MCDA is a field in expansion and shows many application possibilities. Some examples of GIS and MCDA integration may rely on the provision of "voluntary geographic information" (PPGIS Public Participatory GIS) - a problem explored by Bravo and Sluter (2015). Accordingly, Milakis and Athanasopoulos (2014) have presented an example of an application in São Paulo City.

According to Burrough and Mcdonnel (1998), fuzzy logic may be defined as a multicriteria analysis methodology with class characterization, and it does not have or cannot define strict limits between classes. In addition, Oliveira (2005) has stated that the fuzzy logic is recommended to adapt data series in order to treat information imperfections, whereas Castanho (2005) has stated that the advantage of using the fuzzy theory lies on the possibility of mathematically modeling and manipulating inaccurate information natural to human language and, therefore, information provided by non-mathematician specialists at the time to characterize the studied processes. The fuzzy logic allows using values without defining rigid limits between classes.

A fuzzy set is characterized by a membership function that assumes values within the interval $[0,1]$. The membership function in the classical set theory assumes just values such as zero (0), thus indicating that the element does not belong to the set, or one (1), thus indicating that the element belongs to the set. On the other hand, the elements in the fuzzy set theory may be associated with membership degrees between 0 and 1 , thus indicating that they may partially belong to a set (Silva et al. 2011; Oliveira, 2013). The so-called membership function associates values between 0 and 1 with the elements of a given set. However, at the time to choose such functions, one must take into account the context they will be used in so, that both, the number and the format of the membership functions, should be chosen according to the knowledge about the belonging relationship among the different criterion under analysis.

Finally, the number of studies assessing the susceptibility to floods have increased over the last few years (Meyer, Scheuer and Dagmar 2009; Wang et al. 2011; Jun et al. 2013; Musungu et al. 2012; Choi et al. 2013;). The criteria used in most of these studies may be classified as qualitative 
or quantitative. According to Wang et al. (2011), qualitative and semi-quantitative approaches have been widely used in countries where data availability or quality is low (reality is often seen in underdeveloped or developing countries such as China and Brazil) since these approaches allow overcoming the lack of data. On the other hand, according to the authors mentioned above, since these models are wholly or partially subjective, they may vary according to the specialists' knowledge.

\section{The study case: Campina Grande County - PB}

Campina Grande County is located in the countryside of the Northeastern Brazilian region; it is the second largest county in Paraíba State and stands out as an economic and industrial center. Its geographic coordinates are 7013'11" $S$ and 35을' $31^{\prime \prime} W$, and its altitude ranges from 337 to 665 meters above sea level. Its urban area comprises $96 \mathrm{~km}^{2}$, and its estimated population was 402,912 inhabitants, in 2014 (IBGE 2014). According to the last IBGE Census (2010), the urban population accounted for 95\%, in total. The analysis of the 1991, 2000 and 2010 censuses has found that the urban area in Campina Grande County had shown a population increase of approximately $20 \%$, therefore, representing changes in the county such as the increased total area, number of buildings, paved streets, etc.

The urban growth and the interventions in the natural environment have several impacts on the hydrological cycle in urban environments, namely: increased soil imperviousness and, consequently, increased surface runoff volume. Tsuyuguchi (2015) has used a topographic survey, as well as automatic watershed detection and statistical analysis instruments, to delimit the eight main macro-basins (Figure 1) composing the urban area of Campina Grande County, which was coded through Latin-alphabet letters.

The author has taken into consideration several criteria in the analysis and final definition of the boundaries basins, including local drainage experts and visits to validation. The current study adopted the delimitation proposed by Tsuyuguchi (2015). Land use changes are quantified in Table 1. The numbers show that the basins $B$ and $D$ (Bodocongó Basin and Prado Basin, respectively) have demonstrated the highest occupancy rate in a 25-year observation period.

Figure 2 shows areas in Campina Grande County, which were officially classified as "very high" and "high" flood risk according to a study carried out by the Mineral Resources and Research Company (CPRM - Companhia de Pesquisa e Recursos Minerais) in 2013 and made available by the Civil Defense. However, only the flood points characterized as "rainwater invasion" in the households or real estates were taken into consideration in the CPRM mappings. The mapping conducted by the CPRM has highlighted two other areas (a highly-sloped area in Cachoeira neighborhood and the area of the old dumping ground); however, since these areas are not urbanized, they cannot be classified as risk areas, although their occupation must be prevented due to peculiarities inherent to them. These areas were identified on the map in yellow and orange. 


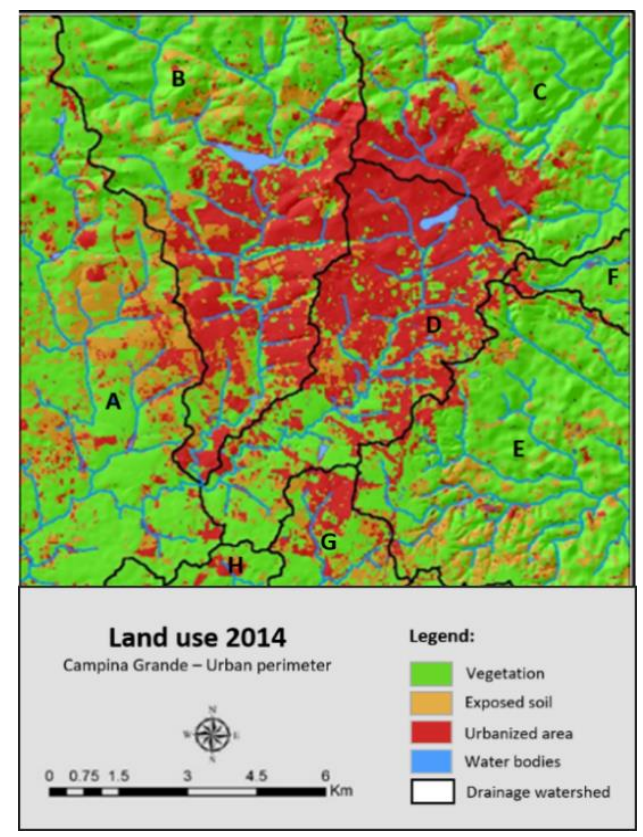

Figure 1: Basins and urban land use (Tsuyuguchi, 2015)

Table 1: Occupancy areas in the basins between 1989 and 2014 (RUFINO et al., 2015)

\begin{tabular}{c|c|c|c}
\hline Basins & $\begin{array}{c}\text { Occupancy area rate } \\
\text { in } \mathbf{1 9 8 9}(\%)\end{array}$ & $\begin{array}{c}\text { Occupancy area rate in } \\
\mathbf{2 0 1 4}(\%)\end{array}$ & $\begin{array}{c}\text { Increase of occupancy } \\
\text { area rate in 25 years (\%) }\end{array}$ \\
\hline A & 1.38 & 7.24 & 5.86 \\
B & 10.54 & 25.48 & 14.94 \\
C & 7.99 & 11.33 & 3.34 \\
D & 32.16 & 56.85 & 24.69 \\
E & 1.58 & 5.68 & 4.1 \\
F & 2.00 & 4.78 & 2.78 \\
G & 2.64 & 20.52 & 17.88 \\
H & 0.07 & 8.01 & 7.94 \\
\hline
\end{tabular}

According to the CPRM, the methodology used to define risk areas comprises: (i) the survey of areas with historical events of natural disasters or risk situations; (ii) field visits conducted in defined areas; (iii) the observation of evidence (topographical situation, slope, rainwater runoff, etc.); (iv) the sector definition and mapping through Google Earth images and; (v) the maps edition in the GIS. Although the CPRM study is extremely important to help taking priority actions given the flooding risks, the county has other areas subjected to frequent flooding (photos at figure 2), but they were not included in the mapping because they are not characterized as "flooded buildings".

Campina Grande has been facing a severe water scarcity in its human supply, which comes from a reservoir located outside the urban area and in another river basin. Even that, it is exposed to floods during the rainy periods, mainly due to the frequency of concentrated rainy events. These events take place often (in rainfall cases) and cause flooding in the county's neighborhoods (Figure 2). These events were also documented in the Municipal Basic Sanitation Plan (PMSB - Plano Municipal de Saneamento Básico), which was prepared from 2013 to 2015 and approved by the technical analysis team. The information in the technical report was checked in the field, through 
the population and data collected by the municipal government of Campina Grande (PMCG Prefeitura Municipal de Campina Grande).

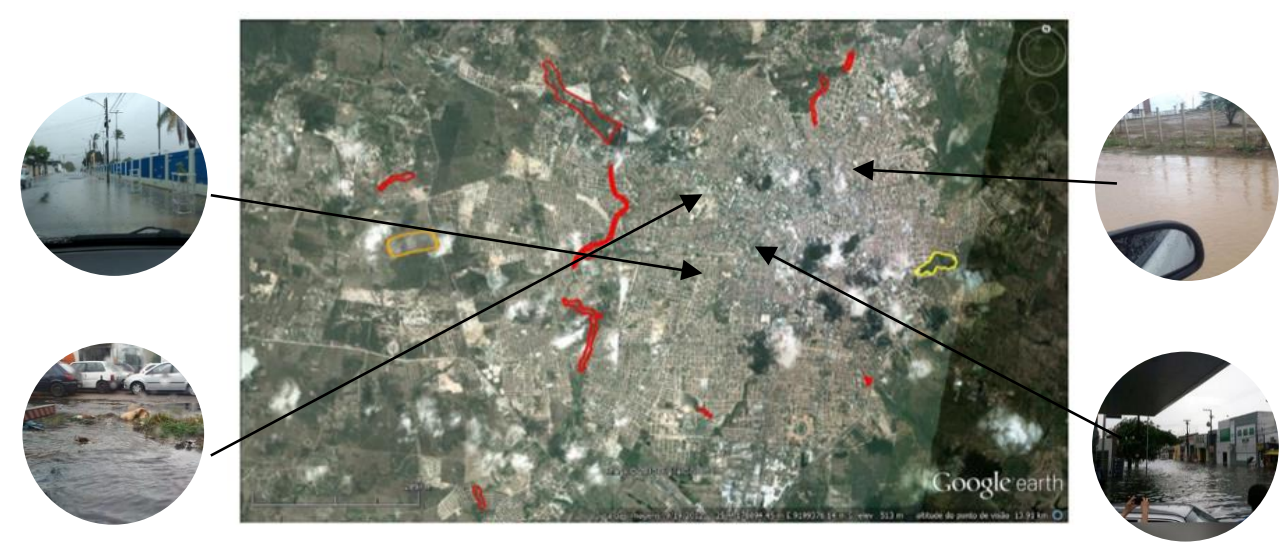

Figure 2: Very high (red) and high floods (yellow) risk areas according to Civil Defense and CPRM (2013) and other flood cases in the municipally

Other authors such as Alves (2017), Santos (2015) and Nóbrega (2012) have described the current urban drainage situation in the county, which includes issues in the cleaning and maintenance of drainage elements such as canals and utility holes, as well as high urbanization and soil imperviousness rates. These facts make the county susceptible to frequent floods and indicate the need for implementing compensatory urban drainage techniques able to mitigate the flooding effects. Tsuyuguchi (2015) has analyzed the macro-drainage and mapped flood points distributed in the county using the Curve Number methodology (CN). The research mentioned comprised interviews conducted with the inhabitants and confirmed the high superficial flows modeled in the areas. Melo Filho et al. (2014) have performed the dimensional analysis of the urban rainwater macro-drainage system towards Piabas Canal (rainwater canal) and identified several points along the network showing irregularities such as the presence of solid wastes, as well as interference from the water and sanitary sewage systems in the county.

The present study has also taken into consideration the discomfort caused by the intersections between important high-traffic roads, since they are relevant to the susceptibility analysis, given the number of traffic accidents recorded during extreme weather events. In addition, material losses and health issues among pedestrians traveling through these areas were recorded, even if their homes were not directly affected by floods.

\section{The model susceptibility to floods}

Studies already developed by other authors (Meyer, Scheuer and Dagmar 2009; Sadeck, Souza and Silva 2012; Zou et al. 2013) were taken into consideration at the time to prepare the conceptual model of susceptibility to floods (detailed in Figure 4 and Table 2) and to define the model's criteria. Thus, given the availability of data concerning Campina Grande County, the analysis performed in the current study has set weights, which were applied pixel by pixel, based on the following premises:

a) Low-altitude areas presenting equally low slope values (flat areas) are more susceptible to floods (according to Tucci (2013), "lower areas are subject to higher flood occurrence"). 
b) Areas close to preexisting water bodies (drains, canals, dams) show greater susceptibility to floods (this premise refers to flood plains, i.e., marginal strips covered due to larger events).

c) Areas close to pathways presenting drainage elements (manholes or rain gutters) are less susceptible to floods due to the rainwater drainage capacity near these elements.

d) Impervious areas will be a restriction in the analysis, i.e., unoccupied regions will not be a priority in the current study, even if they are susceptible to floods.

The herein described premises have generated the criteria used as modeling input. The modeling uses the ArcGIS package (Esri) and its "model builder" tool. This resource enables the automation of the entire modeling process in order to help to load new data with no need to perform all the processing again. Figure 3 shows the developed model and the applied membership functions, in addition to the used tools.

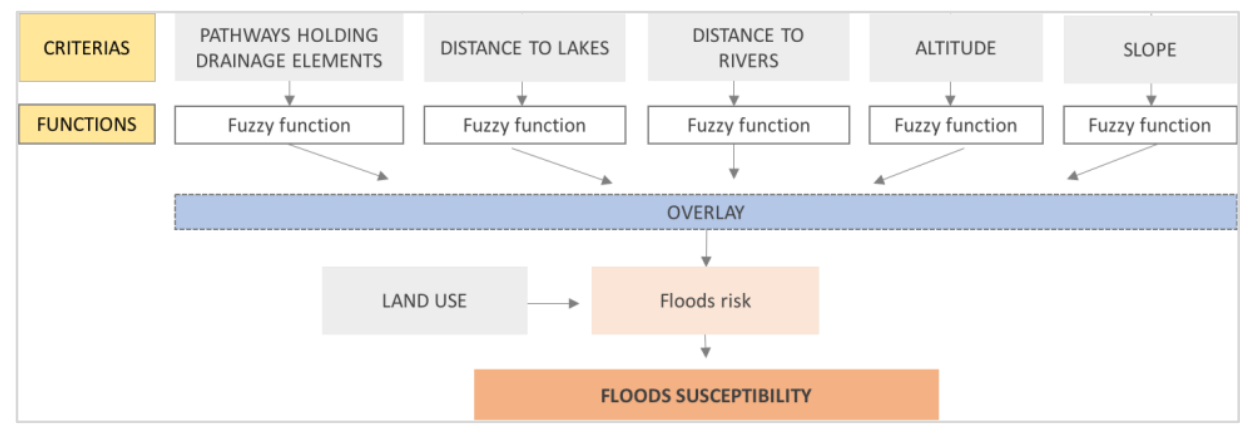

Figure 3: Developed model into "Model Builder" ArcGIS tool

The fuzzy logic concepts developed by Zadeh (1965) were used in the multicriteria analysis. A fuzzy set is characterized by the membership degree, which ranges from 0 to 1 , and indicates the continuous increase from a non-membership situation to a total-membership one, according to a linear function (Figure 4). After the membership functions settled, an overlay was performed by taking into consideration all the already standardized criteria.

a)

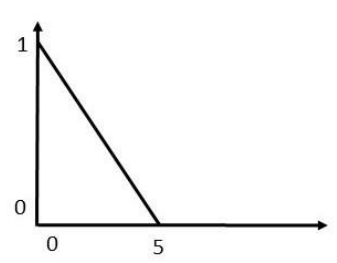

b)

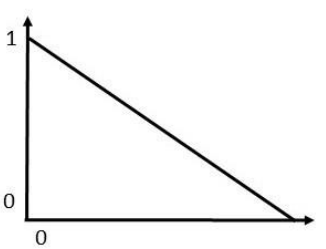

c)

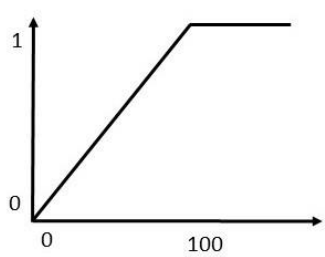

d)

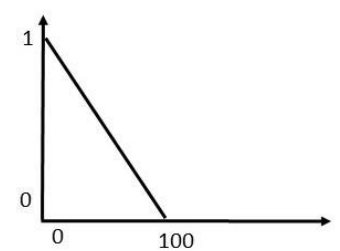

Figure 4: Linear functions of the study case: a) slope; b) altitude; c) pathways holding drainage elements; d) water body (rivers and lakes)

The criteria and the description of the relation between/influence of each criterion and/or the degree of susceptibility to floods in each pixel are detailed in Table 2. All these relations were discussed by the team of researchers based on experts 'knowledge about extreme events (flooding) that took place in the county. The susceptibility model has also incorporated the relation between the adequacy of each criterion and the premises set in the conceptual model.

The five mentioned criteria were converted into a "Fuzzy Member" to allow a fuzzy overlap of them. After the model was executed, the resulting final map was expressed in terms such as 0 and 
1; next, it was classified to allow determining the "high", "medium" and "low" susceptibility thresholds.

Table 2: Criterions to evaluate the susceptibility to floods

\begin{tabular}{|c|c|c|}
\hline Criteria & Description & Data/Source \\
\hline Slope & $\begin{array}{l}\text { It is considered that the flatter the terrain, the more } \\
\text { susceptible it is to flooding. When the slope exceeds } 5 \\
\text { degrees, this criterion no longer affects the final result, since } \\
\text { steeper slopes will not allow the water to accumulate in the } \\
\text { area equivalent to the analyzed pixel, they will make it move } \\
\text { to lower areas. }\end{array}$ & $\begin{array}{l}\text { The slope is automatically } \\
\text { generated from the elevation } \\
\text { model (MDE) - (first } \\
\text { derivative), using GIS' slope } \\
\text { generation tools. }\end{array}$ \\
\hline Altitude & $\begin{array}{l}\text { A continuous linear decreasing function is taken into } \\
\text { consideration (the lower the altitude value, the stronger the } \\
\text { possibility of flooding). }\end{array}$ & $\begin{array}{l}\text { MNT - (Numerical model) } \\
\text { prepared and published by } \\
\text { Tsuyuguchi (2015). }\end{array}$ \\
\hline $\begin{array}{l}\text { Pathways } \\
\text { holding } \\
\text { drainage } \\
\text { elements }\end{array}$ & $\begin{array}{l}\text { A continuous linear increasing function (the closer to a } \\
\text { pathway holding drainage elements, the lower the } \\
\text { possibility of flooding) is taken into consideration in the } \\
\text { interval between } 0 \text { and } 100 \text { meters; from } 100 \mathrm{~m} \text { on, the } \\
\text { weight is constant, i.e., equal to } 1 .\end{array}$ & $\begin{array}{l}\text { Information provided by the } \\
\text { City Hall of Campina Grande } \\
\text { County in shapefile format. }\end{array}$ \\
\hline $\begin{array}{l}\text { Waterbody } \\
\text { (Rivers and } \\
\text { lakes) }\end{array}$ & $\begin{array}{l}\text { A continuous linear decreasing function is taken into } \\
\text { consideration in the interval between } 0 \text { and } 100 \text { meters. In } \\
\text { the current case, from } 100 \text { meters on, is considered the } \\
\text { proximity to the water body is no longer important to the } \\
\text { analyzed pixel. }\end{array}$ & $\begin{array}{l}\text { Basic hydrography of the } \\
\text { county (PMCG 2010) }\end{array}$ \\
\hline Land use & $\begin{array}{l}\text { A restriction is taken into consideration in the analysis: only } \\
\text { impervious areas susceptible to flooding will be taken into } \\
\text { consideration due to the stronger direct impact flooding } \\
\text { have on them. }\end{array}$ & $\begin{array}{l}\text { Rufino, Santos and Tsuyuguchi } \\
\text { (2015) }\end{array}$ \\
\hline
\end{tabular}

\section{Results and Discussions}

The flood susceptibility map, which was generated after the model was executed, is shown in Figure 5. The overlay operations allowed finding that all flood points indicated by the Civil Defense and by the CPRM in the study conducted in 2013 (using different criteria and methodologies) agree with areas considered highly susceptible to flood according to the current methodology. These areas were used to validate the current results.

The other areas, which were not mapped by the CPRM but were identified in the current study as highly susceptible to floods, were validated through a detailed study about previous occurrences in intersections considered important to urban mobility as a whole. In addition, areas indicated by previous studies using different methodologies (Alves 2017; Ramalho et al. 2015; Santos 2015; Tsuyuguchi 2015; Melo Filho et al. 2014; Nóbrega 2012) and by the county's PMSB (2015) were used to compare the results. 


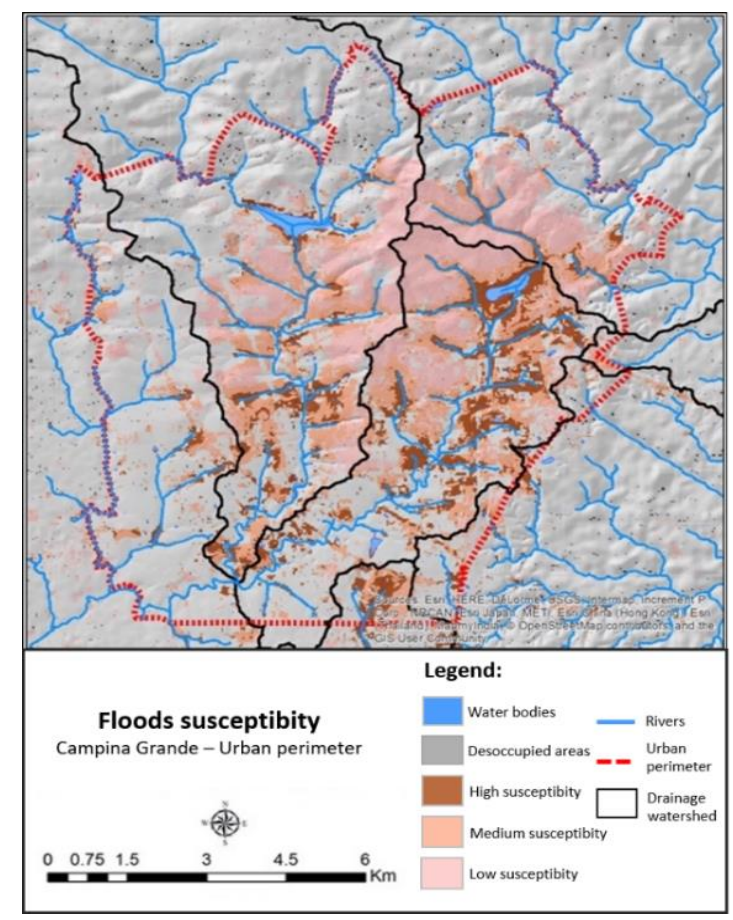

Figure 5: Flood susceptibility map generated with the model

Figures 6 and 7 show urban details where flooding episodes are often and, sometimes, cause several problems to the general population. The figure 6A presents an urban fraction detail in Presidente Médici district (Campina Grande County) showing high susceptibility to floods. The entire area, which was classified as highly susceptible to floods, is inserted in a micro basin belonging to the Bodocongó Creek drainage macrosystem.

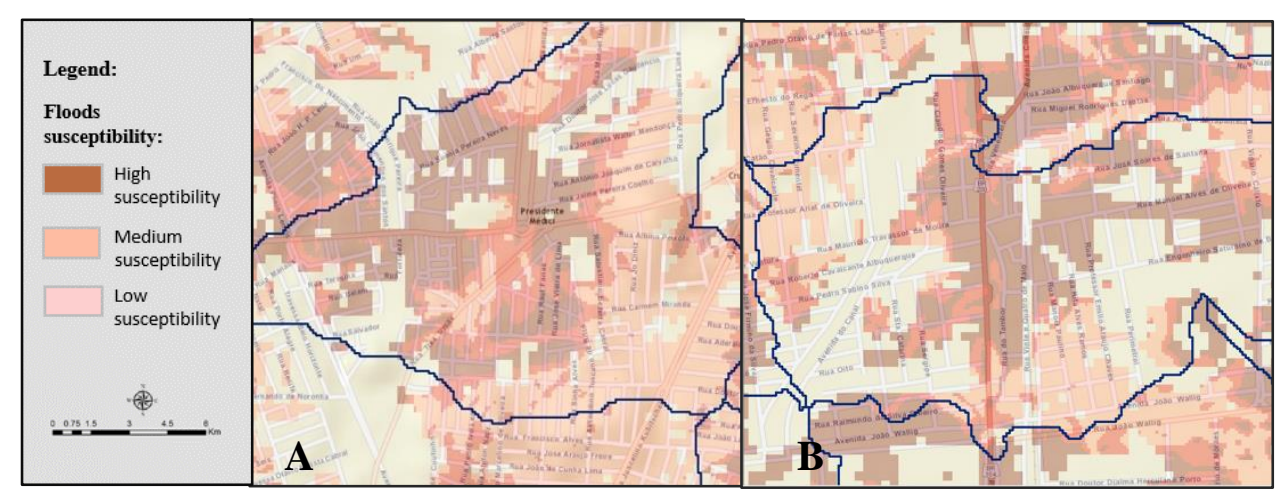

Figure 6: Critical areas (with highly susceptibility areas) in: A) Presidente Médici district; B) Tambor and Industrial district

Tsuyuguchi (2015) has developed a flood map along the main creek belonging to the Campina Grande basins (coinciding with the Presidente Médice district) for 10-year rainfall returns. The map indicates recurrent floods throughout the stream, as well as a high possibility of floodings in houses built in irregular areas (APPs). According to the county's PMSB, the whole neighborhood area showing high susceptibility to floods is part of a micro drainage basin belonging to the Bodocongó Creek drainage macrosystem - one of the basins showing the highest risk area rates.

It is worth highlighting a zone showing high susceptibility to floods between two neighborhoods Tambor and Industrial District - in Southwestern Campina Grande County (Figure 6B). This area 
covers a long stretch of Assis Chateaubriand Avenue, which is one of the high-traffic avenues in the region. Studies conducted by Santos (2015) and Nóbrega (2012) in the areas surrounding these neighborhoods have indicated that the entire region is highly susceptible to floods, (previous shreds of evidence). Ramalho et al. (2015) have classified the whole area as "high risk" and suggested that priority actions could avoid future floods. In addition, the districts are part of the drainage macrosystem of Prado Canal (basin D), which showed the highest imperviousness rates (Table 1); several areas in these neighborhoods were also classified as highly susceptible to flood (according to the current County Master Plan).

Figure 7A indicates another section of the Prado Canal basin along Janúncio Ferreira Avenue, which was characterized as highly susceptible to flood. The most critical points, according to the current methodology, were highlighted with red circles. Those intersections are high-level traffic areas and often are wholly flooded some minutes after an intense raining event.

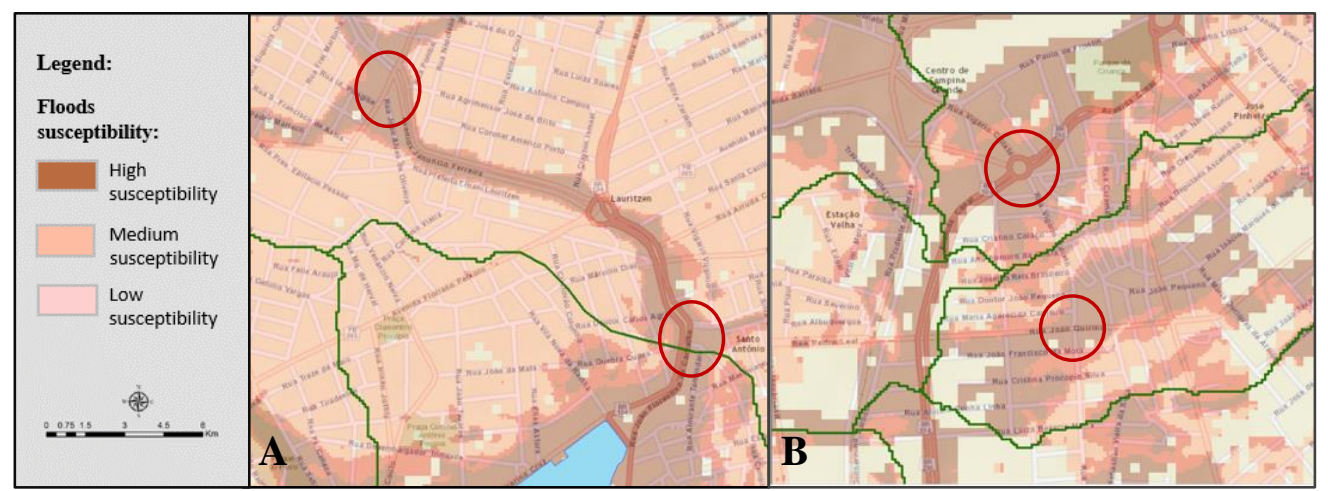

Figure 7: Critical areas (with highly susceptibility areas) in: A) Section of the Prado Canal basin along Janúncio Ferreira Avenue and; B) Catolé neighborhood

According to Alves (2017), most of this macro-basin is highly susceptible to floods and shows high imperviousness and declivity rates. The results have indicated that compensatory drainage measures should be taken to reduce flooding events. Melo Filho et al. (2014) have conducted studies in several points along the canal (including the Piabas Canal) and found irregularities such as the presence of solid wastes, as well as interference from the county's water and sanitary sewage systems. Nóbrega (2012) has surveyed the drainage elements in Prado Canal and found that they were poorly maintained.

Catole is another district belonging to Prado macro-basin (Figure 7B). This area shows high population density and already presents several issues typical to large cities such as lack of mobility and infrastructure, as well as frequent flooding in periods of more intense rains. The intersections highlighted by red circles are often flooded and become inaccessible during more intense raining events. These intersections were also classified as highly susceptible to flood in the herein performed analysis. Santos (2015) carried out an integrated land use and urban drainage analysis in Catole and found that several lots showed more imperviousness than that allowed in the county's current legislation. The author has also used simulations to show that the floodings in the neighborhoods could be reduced if the legislation was fulfilled.

The highlighted urban fractions (Figures 6 and 7) were selected because they are areas where it is possible seeing frequent flooding episodes, which sometimes cause several problems to the general population. Thus, the herein used model has shown satisfactory results and may be used as a proper planning and management instrument. Concerning the quantitative assessment, 100\% 
of the areas delimited by the CPRM have agreed with the results of this modeling. Besides, surveys using different methodologies, as well as official PMSB data, have shown several areas where flooding are recurrent, a fact that indicates the magnitude of the cases and the probable disturbances faced by the population. It is also worth citing local newspapers that, at the end of 2014, for example, reported a significant disorder that took place precisely in Catolé area which was indicated by the model as highly susceptible to floods.

\section{Conclusions}

The current article has mapped the flood susceptibility of Campina Grande County (PB), through a multicriteria analysis conducted in the ArcGIS (Esri) software. The flood map shows critical points in the county according to the current land-use scenario (imperviousness), by taking into consideration criteria such as the presence of drainage elements, the distance from lakes and rivers, altitude and declivity. This type of integrated approach plays a crucial role in the management and can help cities to prevent and prepare for disasters, such as floods effectively.

After the results generated by the flood susceptibility model (Figure 4) were validated and analyzed, the model was considered a potential planning and management instrument to be included in the county's current legislation. The described methodology can support the decision analysis necessary to address and prioritize interventions in order to mitigate risk and avoid disorder caused by recurrent flooding episodes. The herein achieved detail level allows identifying areas on a relatively large scale through the identification of the exact section of the street where the model suggests high flooding risk. Thus, the managers' performance can be optimized enough to allow them identifying the precise areas needing immediate actions, as also medium- or longterm planning, according to the susceptibility degree indicated for each area. For example, these specific aspects can be added to the current CPRM data after this analysis.

Despite the lack of information about the herein observed drainage system, which is characteristic of most Brazilian counties, the model was valid and coherent. The digital elevation model, combining topographic survey, remote sensing data and testing different interpolation methods, provided consistent primary data and was critical to reaching the verified compatibility between the results of the present study and those found in previous studies.

Therefore, the current approach appears as a parallel option to the applicable use of hydrological and hydrological-hydraulic models, since it uses some of the concepts such models are based on. Although it was a simplified analysis, the spatialized and joint assessment based on the available topography and infrastructure data concerning Campina Grande County allowed optimizing the use of these data and highlighted the importance of having the public power improving the database in order to help a better understanding of the county's nuances. Further studies should be conducted using other variables affecting water runoff, such as soil type, by refining the adequacy functions and adopting different weights for the criteria.

\section{ACKNOWLEDGEMENT}

The authors are grateful to CNPq and CAPES, for granting Ph.D. students scholarships; as well as to the City Hall of Campina Grande County and the Municipal Basic Sanitation Plan team. 


\section{REFERENCES}

Alfy, M. E. 2016. Assessing the impact of arid area urbanization on flash floods using GIS, remote sensing, and HEC-HMS rainfall-runoff modeling. Hydrology Research, 47(6), pp. 1142-1160

Alves, P. B. R. 2017. Simulações de medidas compensatórias sustentáveis de drenagem: propostas em duas microbacias urbanas. Dissertation. Federal University of Campina Grande.

Amorim, M. F. Quelhas, O. L. G. and Motta, A. L. T. S. 2014. The resilience of cities across the torrential rains: Case study of the contingency plan of the city of Rio de Janeiro (Brazil)". Sociedade \& Natureza, 26(3), pp. 519-534

Bazerman, M. H. 2006. Judgment in Managerial Decision Making. 6th ed. Hoboken, NJ: John Wiley \& Sons, Inc.

Bravo, J. and Slutter, C. R. 2015. O problema da qualidade de dados espaciais na era das informações geográficas voluntárias. Boletim de Ciências Geodésicas, 21(1), pp.56-73.

Burrough, P. A. and Mcdonnell, R.A. 1998. Principles of geographical information systems. 2nd ed. Oxford: Oxford University Press.

Castanho, M. J. P. 2005. Construção e avaliação de um modelo matemático para predizer a evolução do câncer de próstata e descrever seu crescimento utilizando a teoria dos conjuntos Fuzzy. PhD. UNICAMP.

Chang, Y-H. Yeh, C-H. and Chang, Y-W. 2013 A new method selection approach for fuzzy group multicriteria decision making. Applied Soft Computing, 13(4), pp. 2179-87.

Chen, S-M. and Hong, J-A. 2014. Multicriteria linguistic decision making based on hesitant fuzzy linguistic term set and the aggregation fuzzy sets. Information Sciences, 286, pp. 63-74.

Choi, H. II. Park, S. Y. Song, J. H. and Park, M. J. 2013. Identification of Flood Risk Areas using a Multi-Criteria Decision Making Method. Journal of Korean Society of Hazard Mitigation, 13(2), pp. $237-43$

Connolly, T. Arkes, H. R. and Hammond, K. R. eds. 2000. Judgment and Decision Making: an interdisciplinary reader. 2nd ed. New York: Cambridge University Press.

CPRM - Serviço Geológico do Brasil \& Defesa Civil - Campina Grande, PB. 2013. Ação Emergencial para Delimitação de Áreas em Alto e Muito Alto Risco a Enchentes e Movimentos de Massa. Campina Grande, Paraíba.

Dheena, P. and Mohanraj, G. 2011. Multicriteria decision-making combining fuzzy set theory, ideal and anti-ideal points for location site selection. Expert Systems with Applications, 38(10), pp. 13260-65.

Ferreira, B. C. and Valverde, M. C. 2013. Comparative analysis between the floods and the rate of urbanization in the Ribeira Valley, São Paulo - Brazil. In: AGU (American Geophysical Union), Spring Meeting.

Goodchild, M. F. Kemp, K. K. eds. 1990. NCGIA Core Curriculum: Introduction to GIS. National Center for Geographic Information and Analysis, University of California, Santa Barbara.

Ho, W. Xu, X. and Dey, P. K. 2010. Multi-criteria decision making approaches for supplier evaluation and selection: a literature review. European Journal of Operational Research, 202(1), pp. 16-24. 
Hotaling, J. M. Fakhari, P. Busemeyer J. R. Dynamic Decision Making. 2015. International Encyclopedia of the Social \& Behavioral Sciences (Second Edition), pp. 708-13.

IBGE, Diretoria de Pesquisas, Coordenação de População e Indicadores Sociais. 2014. Available at: $<$ https://cidades.ibge.gov.br/brasil/pb/campina-grande/panorama> [Accessed in August 2017]

Jun, K-S. Chung, E-S. Kim, Y-G and Kim, Y. 2013. A fuzzy multi-criteria approach to flood risk vulnerability in South Korea by considering climate change impacts. Expert Systems with Applications, 40 (4), pp. 1003-13

Kahneman, D. and Tversky, A. 2000. eds. Choices, Values and Frames. New York: Cambridge University Press.

Kleindorfer, P. R., Kunreuther, H. C. and Schoemaker, P, J. H. 1993. Decision Sciences: an integrative perspective. New York: Cambridge University Press.

Koehler, D. J. and Harvey, N. eds. 2005. Blackwell Handbook of Judgment \& Decision Making. United Kingdom: Blackwell Publishing,

Lakicevic, M. Srdjevic, Z. Srdjevic, B. and Zlatic, M. 2014. Decision making in urban forestry by using approval voting and multicriteria approval method (case study: Zvezdarska Forest, Belgrade, Serbia). Urban Forestry \& Urban Greening, 13(1), pp. 114-20.

Malczewski, J. 2006. GIS-based multicriteria decision analysis: a survey of the literature. International Journal of Geographical Information Science, 20(7), pp. 703-26.

Melo Filho, H.; Feitosa, P. H. C.; Freire, J. R. P. and Rocha, M. D. 2014. Avaliação do sistema de Drenagem Pluvial da cidade de Campina Grande - Paraíba. In: ABRH (Associação Brasileira de Recursos Hídricos), XII Simpósio de Recursos Hídricos do Nordeste. Natal, Rio Grande do Norte, 0407 November 2014. Porto Alegre: ABRH.

Meyer, V. Scheuer, S. and Dagmar, H. 2009. A multicriteria approach for flood risk mapping exemplified at the Mudle River, Germany. Natural Hazards, 48(1), pp. 17-39.

Milakis, D. and Athanasopoulos, K. 2014. What about people in cycle network planning? Applying participative multicriteria GIS analysis in the case of Athens metropolitan cycle network". Journal of Transport Geography, 35, pp. 120-29

Miller, J. D., Kim, H. Kjeldsen, T. R. Packman, J. Grebby, S. and Dearden, R. 2014. Assessing the impact of urbanization on storm runoff in a peri-urban catchment using historical change in impervious cover. Journal of Hydrology, 515, pp. 59-70.

Moura, A.C.M. 2007. Reflexões metodológicas como subsídios para estudos ambientais baseados em Análise de Multicritérios. In: INPE (Instituto Nacional de Pesquisas Espaciais), Simpósio Brasileiro de Sensoriamento Remoto, Florianópolis, Brasil, 21-26 april 2007. São José dos Campos: INPE.

Musungu, K. Motala S. and Smit, J. 2012. Using Multi-criteria Evaluation and GIS for flood risk analysis in informal settlements of Cape Town: the case of Graveyard Pond. South African Journal of Geomatics, 1(1), pp. 77-91.

Nobrega, P. V. Analise do Sistema de Drenagem de Campina Grande/PB para proteção de areas de riscos de inundação. Dissertation. Federal University of Campina Grande, 2012.

Norwegian Water Resources and Energy Directorate (NVE). 2012. Challenges in Flood Risk Management Planning [pdf]. Norway: Norwegian Water Resources and Energy Directorate. 
Available at: < http://publikasjoner.nve.no/rapport/2012/rapport2012_16. pdf > [Acessed 20 April 2017]

Oliveira, A. L. S. 2013. Modelagem espacial de predição de riscos de incêndios com lógica fuzzy, comparação e validação. Dissertation. Federal University of Pernambuco.

Oliveira, A. M. 2011. Indicadores de vulnerabilidade e risco socioambiental para prevenção e mitigação de desastres naturais na Bacia do Rio Jari. Dissertation, UNIFAP.

Ramalho, P. B. Rufino, I. A. A. Feitosa, P. H. C. Estimativa de potenciais problemas na microdrenagem urbana a partir de uma avaliação multicriterial espacial. $5 a$ Reunião de Estudos Ambientais, 2015, Porto Alegre.

Roy, B. and Vincke, P. 1981. Multicriteria analysis: survey and new directions. European Journal of Operational Research, 8(3), pp. 207-18

Rufino, I. A. A. Santos, R. C. and Tsuyuguchi, B. B. Estimativas de taxas de impermeabilização do solo nas bacias urbanas do município de Campina Grande-PB utilizando sensoriamento remoto". In: INPE (Instituto Nacional de Pesquisas Espaciais), XVII Simpósio Brasileiro de Sensoriamento Remoto. João Pessoa, Paraíba, 25-29 April 2015. Porto Alegre: INPE.

Sadeck, L. W. R. Souza, A. A. A. and Silva, L. C. T. 2012. Mapeamento das zonas de risco às inundações no município de Belém - PA. In: VI Encontro Nacional da Anppas. Belém, Pará, 18-21 September.

Santos, K. A. 2015. Análise integrada da permeabilidade do solo nos bairros Catolé e Sandra Cavalcante em Campina Grande. Dissertation. Federal University of Campina Grande.

Shaw, E. M. Beven, J. K. Chappel, A. N and Lamb, R. 2011. Hydrology in practice. 3rd ed. New York: Spon Press.

Smith, K. Shanteau, J. and Johnson, P. eds. 2004. Psychological investigations of competence in decision making. New York: Cambridge University Press.

Tan, C. Yi, W. And Chen, X. 2015. Hesitant fuzzy Hamacher aggregation operators for multicriteria decision making. Applied Soft Computing, 26, pp. 325-49

Tsuyuguchi, B. B. 2015. Macrodrenagem e a ocupação do solo no município de Campina Grande$P B$, caracterização, simulação e análises sistêmicas. Dissertation, Federal University of Campina Grande,.

Tucci, C. E. M. 2013. Hidrologia: Ciência e Aplicação. Porto Alegre: Editora da UFRGS/ABRH.

Tucci, C. E. M. 2007. Inundações Urbanas. Porto Alegre-RS: ABRH.

Wang, J-J. Jing, Y-Y. Zhang, C-F. and Zhao, J-H. 2009. Review on multi-criteria decision analysis aid in sustainable energy decision-making. Renewable and Sustainable Energy Reviews, 13(9), pp. 2263-78

Wang, Y. Li, Z. Tang, Z. and Zeng, G. 2011. A GIS-based Spatial Multi-criteria Approach for Flood Risk Assessment in the Dongting Lake Region, Hunan, Central China. Water Resources Management, 25(13), pp. 3465-84

Wilson, D. Anderson, B. Robinson, J. Comeadow, S. and Dale, E. 2014. The Bureau of meteorology's recent improvements in Australia's flood warning system. In: Hydrology and Water Resources Symposium. Perth, Australia, 24-27 February 2014, Barton ACT: Engineers Australia. 
World Bank. 2014. The World Bank Annual Report 2014. Washington, DC. (C) World Bank. https://openknowledge.worldbank.org/handle/10986/20093 License: CC BY-NC-ND 3.0 IGO

Zadeh, L. A. 1965. Fuzzy sets. Information and Control. 8(3), pp. 338-53.

Zou, Q. Zhou, J. Zhou, C. Song, L. and Guo, J. 2013. Comprehensive flood risk assessment based on set pair analysis-variable fuzzy sets model and fuzzy AHP. Stochastic Environmental Research and Risk Assessment, 27(2), pp. 525-546. 